\title{
Use of Distributed Electricity Generation Technologies in Hotels
}

\author{
John Vourdoubas \\ Consultant Engineer, 107 B, El. Venizelou str., Chania, Crete, Greece \\ E-mail: vourhome@otenet.gr
}

Received: January 26, 2021

Accepted: April 5, $2021 \quad$ Published: April 11, 2021

doi:10.5296/ijgs.v5i1.18522

URL: https://doi.org/10.5296/ijgs.v5i1.18522

\begin{abstract}
Distributed electricity generation technologies have increasing applications worldwide in various sectors due to their environmental and economic benefits. In the present study the use of these technologies in hotel industry is investigated. Various distributed electricity technologies, including co-generation of heat and power systems, are examined. Some of them are using renewable energies like solar energy, wind energy and biomass for electricity generation. Others are related with various co-generation systems including fuel cells. Many hotels require almost equal amounts of heat and electricity in their daily operations. Co-generation technologies have the advantage that they can cover almost all of their requirements in both electricity and heat. Some distributed electricity generation technologies including solar photovoltaic energy, co-generation systems, wind turbines and fuel cells are already used in hotels. Their energy efficiency varies in the range of $10 \%$ to $90 \%$. Technologies using renewable energies generate carbon-free electricity while others fueled by natural gas generate electricity with low carbon impacts. Each technology has advantages and drawbacks while the possibility of using each technology depends on hotel's characteristics as well as on the local availability of renewable energy sources. The results of the present study are important in hotel industry since they indicate the possibility of using the environmentally friendly distributed electricity generation technologies for covering their electricity as well as, in some cases, their heating requirements reducing their carbon footprint due to energy use and increasing their energy and environmental sustainability.
\end{abstract}

Keywords: Biomass, Co-generation systems, Distributed electricity generation, Fuel cells, Hotels, Renewable energies, Solar energy, Wind energy

\section{Introduction}

Distributed energy generation systems have many advantages compared with traditional energy generation systems and their use is growing rapidly worldwide. Among them, 
distributed electricity generation (DEG) technologies using either fossil fuels or renewable energies have increasing applications in developed as well as in developing countries. Hotel buildings consume a lot of energy compared with other types of buildings. They utilize mainly conventional fuels and electricity including natural gas, heating oil and grid electricity. Use of renewable energy technologies in them is rather limited. Present research is focused in the investigation of the possibility of using DEG technologies in hotels. The characteristics, advantages and drawbacks of various DEG systems which can provide either electricity or both heat and electricity to them, covering part or all of their energy needs, are mentioned. Although these technologies have many economic, environmental and social benefits their current use in the hospitality industry, due to various reasons, is rather limited. Some technologies are already used in hotels while others could be used in the future. Present research is important since it indicates that various cost effective DEG technologies can be used in hotels for electricity and/or heat generation improving their energy and environmental sustainability.

\section{Literature survey}

\subsection{Distributed Energy Generation Systems}

Paliwal et al. (2014) have reviewed technology, objectives and applications of distributed energy generation systems. The authors stated that most of the existing distributed generation (DG) systems are based on fossil fuels. They also mentioned that assessment of DG system's performance should be based in a holistic consideration of various parameters. Chow et al. (2012) have reviewed the building's integration with hybrid solar photovoltaic-thermal systems. The authors stated that hybrid photovoltaic/thermal (PV/T) systems have been studied in depth during the past decades. They also mentioned that they are important in the creation of low carbon energy buildings. Good et al. (2015) have reviewed the use of hybrid solar photovoltaic-thermal systems in buildings. The authors mentioned that PV/T systems convert solar radiation to heat and electricity simultaneously. They also stated that these systems are useful in buildings with limited space availability. An economic evaluation of small-scale distributed electricity generation technologies has been published, 2003. The report mentioned that small scale DG systems are useful in rural areas without electric grid infrastructure. These systems can be also used with conventional energy technologies in hybrid systems to provide electricity in remote locations and rural areas. Hidayatullah et al. (2011) have analyzed the DG systems and the smart grid technologies. The authors stated that the global electricity sector faces great challenges related with energy security and efficiency as well as with climate change. They mentioned that smart grid technologies and DEG systems can assist in reliable and affordable green electricity generation and distribution. Moroni et al. (2019) have studied and analyzed the idea of distributed energy generation systems and energy communities. The authors have focused on four topics related with: a) The concept of distributed energy generation systems, b) Why distributed generation is ethically desirable, c) Why people consider energy communities a positive idea, and d) Can energy communities be considered different that state intervention and market systems. Purchala et al. (2006) have investigated DEG systems and their integration into the grid. The authors mentioned that International Energy Agency listed five major technological factors 
which have contributed to DEG including: a) Developments in distribution generation technologies, b) Constraints in the construction of new transmission lines, c) increased customer demand for highly reliable electricity, d) liberalization of the electricity market, and e) climate change. Huang et al. (2006) have overviewed fuel cell technology for distributed energy generation. The authors stated that fuel cells consist of a promising energy generation technology. Although, they mentioned, their capital cost is still high they are expected to play an important role in DEG systems in the future.

\subsection{Use of Distributed Electricity Generation Systems in Hotels}

Santamouris et al. (1996) have studied the energy conservation and the retrofitting potential in Hellenic hotels. The authors analyzing energy data from 158 Hellenic hotels stated that their annual energy consumption was at $273 \mathrm{KWh} / \mathrm{m}^{2}$. They also mentioned that the adoption of energy saving measures can reduce their energy consumption by $20 \%$. Bohdanowicz et al. (2001) have reported on energy efficiency and sustainability in hotels. The authors mentioned that energy costs typically amount at 3-6\% in their overall operational costs while electricity is the primary energy source in hotel industry. The use of solar energy in Indian hospitality industry has been reported, 2014. The report mentioned that there is a growing trend all over the world for creation of green hotels. Renewable energy applications in Indian hotels include the use of solar photovoltaic (solar-PV) systems, solar steam generation systems and solar water heating systems. Bischoff et al. (2016) have studied the use of renewable energy technologies in a new hotel building located in Amsterdam. The authors stated that solar-PV energy can cover a significant amount of the hotel's energy requirements. They also mentioned that other green energy technologies like small wind turbines and co-generation of heat and power (CHP) systems can be also used. Cannistraro et al. (2016) have studied the use of CHP systems in hospitality industry. The authors investigated the technical and economic feasibility of a CHP plant fueled by natural gas in a hotel located in northern Italy. They stated that use of CHP systems in hotels increases the reliability and efficiency of the energy system while its proper sizing regarding generation of electricity, heat and cooling is very important. Horiuchi et al. (2001) have reported on fuel cell applications in various industries. The authors mentioned that fuel cells are suitable in hotel industry providing heat and electricity in an efficient and reliable way. The installation of a CHP system in the Millennium hotel and resort located in New York has been announced (2012). The capacity of the hotel is 750 rooms while the CHP system is consisted of three CHP units using reciprocating engines at $250 \mathrm{KW}$ el each. Borello et al. (2013) have studied the use of a CHP system based on biomass and concentrated solar power in a hotel. The authors, using computer simulation techniques, mentioned that the energy system was successfully matching the thermal and electricity needs in the hotel. They also stated that the unit cost of the energy system was high at $7200 \$ / \mathrm{KW}$ mainly due to its solar part. The possibility of using CHP systems in middle size and large hotels has been reported, 2008. The report stated that for hotels with capacity at 100 to 500 rooms the size of the optimum CHP systems is in the range from $60 \mathrm{KW}_{\text {el }}$ to $350 \mathrm{KW}$ el depending on the size and the energy requirements of the hotel. It is also mentioned that these energy systems increase the energy efficiency and reduce the operating costs while provide hot water and electricity reliably. A study on 
renewable energy use in tourist accommodation buildings has been realized, 2013. The aim of this study was to assist tourist accommodation enterprises to reduce their carbon footprint. Various green technologies used in different hotels located in various countries concerning energy saving measures and renewable energy utilization have been mentioned in the study. Use of straw for CHP in a hotel located in north-east black sea coast, Bulgaria has been reported. The electric power of the CHP plant is $500 \mathrm{KW}_{\mathrm{el}}$ and its heat power at $2320 \mathrm{KW}_{\text {th }}$ while the annual electricity generation is $4.3 \mathrm{GWh}_{\mathrm{el}}$ and the annual heat generation at 16 $\mathrm{GWh}_{\text {th. }}$ Vourdoubas (2019) has investigated the possibility of using solar thermal and solar-PV energy for creating carbon neutral hotels due to energy use in Mediterranean region zeroing their carbon footprint due to energy use. The author stated that solar thermal energy combined with high efficiency heat pumps can cover all energy requirements in summer operating hotels located in Mediterranean region. He also estimated the capital cost of the necessary green energy technologies in a typical hotel at $95.7 € / \mathrm{m}^{2}$ of its covered area while its $\mathrm{CO}_{2}$ emission savings at $68 \mathrm{kgCO} / \mathrm{m}^{2}$. Vourdoubas has studied the use of fuel cells for energy generation in Greek hotels. The author stated that fuel cells could play an important role in the future as distributed energy generation systems providing heat and electricity in hotels. However, he mentioned, their commercial promotion requires financial from the government. The first energy positive hotel is under development. The hotel is located in Meloy municipality, Norway close to Svartisen glacier. Energy consumption in the hotel will be low while its energy needs will be covered with solar energy. Green energy systems installed in the hotel are expected to generate all its annual operating energy and additionally its embodied energy as well as the energy required in various adjacent services. Hotel Stadthalle located in Vienna Austria is the first hotel with zero energy balance. The hotel generates within a year as much energy as it consumes via its groundwater heat pump, a solar-PV system and solar thermal panels. Additionally it offers to its guests green bonus encouraging them to travel with reduced- $\mathrm{CO}_{2}$ means of transportation. Use of micro-grids as an effective energy solution in hotels has been reported. It is mentioned that TWA hotel in JFK airport, USA has become energy self-sufficient using a gas-fired co-generation system. It is also stated that a precise energy analysis is required in order to indicate the right mix of heat and electricity generation by a CHP system installed in a hotel which is necessary for assessing its profitability. A report on the installation of six (6) wind turbines in Hilton Fort Lauderdale beach resort hotel located in south Florida, USA has been published. Wind turbines placed on the rooftop of the buildings are expected to generate $24000 \mathrm{KWh} / \mathrm{year}$ reducing the annual electricity bill by $5-10 \%$. Alujevic has reported on energy use in hotels on the Adriatic coast in Croatia. The author stated that the average annual energy consumption in hotels on the Adriatic coast is in the range of $159 \mathrm{KWh} / \mathrm{m}^{2}$ to $180 \mathrm{KWh} / \mathrm{m}^{2}$ and of $162 \mathrm{KWh} / \mathrm{m}^{2}$ to $225 \mathrm{KWh} / \mathrm{m}^{2}$ for seasonal and non-seasonal operating hotels respectively. Huacuz has studied a hybrid PV-wind energy system installed in an ecological hotel located in South Mexico. The hybrid system was consisted of one wind generator, one solar-PV panel with nominal power at $150-320 \mathrm{~W}$ and one lead-acid battery at $570 \mathrm{Ah}$. The author mentioned that the operation of the energy system was successful assisting in its future commercial development. Parpairi has studied the energy use and sustainability in small scale Greek hotels. The author stated a list of measures which are often used in Greek hotels 
aiming in higher penetration of renewable energies in their energy mix. She also mentioned that hotel owners can choose among various available strategies regarding the improvement of energy efficiency and environmental sustainability in their enterprises. Integration of successful and efficient energy technologies in SME hotels, 2011 has been reported. The report mentioned eighteen (18) case studies in small to medium size hotels located in EU countries concerning the improvement in their energy efficiency. According to the report in order to find the optimum energy technologies in a hotel an initial energy evaluation is required followed by organizational behavioral changes and selection of the best technical innovative solutions. A report regarding the use of small wind energy systems in hotels has been published. The report stated that when wind resources at hotel's premises are satisfactory wind turbines can be installed. Additional requirements for using wind turbines include space availability and legal regulations allowing their installation. It is also mentioned that investments in wind turbines can be financed by energy service companies. Perfetto et al. (2016) have studied a zero energy hotel combined with sustainable mobility in Rhodos island, Aegean sea. The authors stated that the high solar irradiance in Aegean sea allows the use of solar energy for electricity generation covering the energy needs of a summer operating hotel in the region. Additionally, they mentioned, solar electricity can produce electrolytic $\mathrm{H}_{2}$ which can be used in powering fuel cell vehicles resulting in zero-carbon mobility.

\subsection{Aim of the Current Research Is to Investigate the Possibility of Using Distributed Electricity Generation Technologies in Hotels}

Initially the existing literature is surveyed and the operating energy consumption in different hotel sectors is stated. Various distributed electricity generation technologies are mentioned while the possibility of using them in hotels is examined. Discussion of the findings and the conclusions drawn are stated together with proposals for further research.

\section{Energy Consumption in Hotels}

Hotels consume energy in various sectors including space heating and cooling, domestic hot water production, lighting and operation of various electric equipment and devices. The distribution of energy consumption per sector varies depending on various parameters including local climate, type of construction, size of the hotel, period of operation and behavior of tourists. Existing studies indicate that hotel buildings are among the highest energy-consuming buildings. The main energy source used in their premises is electricity, followed by fossil fuels while the share of renewable energies in their energy mix is rather low. Energy cost in hotels has low impact in their total operating cost which is estimated at around 3-6\%. Due to the low impact of energy cost in hotels' profitability hoteliers do not bother to deal with or to try to reduce it. The energy consumption per end-use in a typical hotel is presented in Table 1. 
Table 1. Energy efficiency of various distributed electricity generation systems

\begin{tabular}{ll}
\hline Hotel sector & Energy consumption (\%) \\
\hline Cooling & 15 \\
Lighting & 12 \\
Space heating & 31 \\
Hot water production & 17 \\
Cooking & 5 \\
Ventilation & 4 \\
Refrigeration & 3 \\
Office equipment & 4 \\
Others & 9 \\
Total & 100 \\
\hline
\end{tabular}

Source: Alujevic, 2006.

Table 1 indicates that in a typical hotel both space heating and hot water production represent almost the half of its total energy needs. The remaining half is related with electricity consumption.

\section{Distributed Electricity Generation Systems}

Various distributed electricity generation systems have been used so far in hotels either fueled by fossil fuels or by renewable energies as it is described below.

\subsection{Systems Using Fossil Fuels}

Distributed electricity generation systems fueled by fossil fuels usually co-generate heat and power. They include small or micro gas turbines, reciprocating engines, fuel cells etc. These systems are usually fueled by natural gas while they have high overall efficiencies in the range of $80-95 \%$. Apart from electricity most of them co-generate heat utilizing the high temperatures of the flue gases. The ratio of power to electricity in these systems varies and they can cover both the electricity and heating needs of the consumer/hotel. Due to their high efficiencies and to fuel used their carbon emissions are relatively low. In cases that they are fueled by biogas the electricity generation is carbon-free. These systems are used in various commercial applications generating energy in buildings, industry and in agriculture as well as in other sectors particularly when both heat and electricity are required by the end user. Due to their high efficiencies they are a preferable option for low carbon emissions energy generation contributing to climate change mitigation. In many countries the electricity generated by these systems can be injected into the grid with attractive feed-in tariffs. Fuel cells co-generate electricity and heat with electrochemical processes fueled by $\mathrm{H}_{2}$. Hydrogen is mainly derived from natural gas while it can be also produced by water electrolysis and solar or wind electricity. Operation of fuel cells with green electrolytic $\mathrm{H}_{2}$ results in carbon-free heat and electricity generation. Fuel cell efficiencies are in the range at 40-60\% for electricity generation and at $30-40 \%$ for heat production resulting in high overall 
efficiencies at around $80-85 \%$. Their capital cost is high but due to their high efficiencies they are usually supported financially.

\subsection{Systems Using Renewable Energies}

Use of DEG systems in hotels and in various other applications is facilitated when the electric grid can be used as an electric battery storing the generated electricity when it is not needed by the end user. This is currently allowed in many countries with net-metering regulations. Among renewable energies which can be used in DEG systems are:

a) Solar energy with photovoltaic panels. Solar-PV systems generating electricity are currently used in many applications in stand-alone systems as well as in various buildings. Solar-PV technology is mature, reliable and cost effective while solar cell prices have been substantially reduced during the last years. These benign energy systems can be used in small, medium and large size hotels generating part or all of their electricity requirements.

b) Hybrid solar PV/T systems can generate both electricity and heat in hotels. Currently their use is limited and further technological development is required in order to increase their commercial deployment.

c) Solar thermal power systems can also generate both heat and electricity in hotels. Like solar PV/T systems they can provide electric and thermal energy in hotels but improvements in their reliability and cost-effectiveness is required for their future deployment in hotel industry.

d) Wind turbines can be installed in hotels generating electricity. High average wind velocity in hotel's premises is prerequisite for using small wind turbines in electricity generation.

e) Solid or gaseous biomass can be used in hotels for heat and power co-generation. Biomass used should be located nearby the hotel's location in order to minimize its transportation cost. There are though limited applications of biomass use for electricity generation in hotels so far.

f) Co-generation of heat and power systems can be used mainly in medium or large size hotels providing electricity and heat. Gas turbines or reciprocation engines are among the main technologies used. Most of these systems are fueled by natural gas while biogas can be also used, if available, in these systems.

g) Fuel cells can also co-generate heat and power. Their use in hotels can cover part or all of their requirements in heat and electricity. They are fueled by $\mathrm{H}_{2}$ produced either from reforming natural gas or by water electrolysis. Both CHP systems and fuel cells are very efficient and low (or zero) carbon emissions energy generation systems.

The energy efficiency of the abovementioned DEG systems is presented in Table 2. 


\section{Macrothink}

Table 2. Energy efficiency of various distributed electricity generation systems

\begin{tabular}{lll}
\hline $\begin{array}{l}\text { Distributed electricity } \\
\text { generation system }\end{array}$ & Electric energy efficiency & $\begin{array}{l}\text { Total energy efficiency } \\
\text { (electric plus thermal) }\end{array}$ \\
\hline $\begin{array}{l}\text { Solar-PVs } \\
\text { Hybrid solar PV/T }\end{array}$ & $15-18 \%$ & $15-18 \%$ \\
$\begin{array}{l}\text { Solar thermal power systems } \\
\text { Wind turbines }\end{array}$ & - & $50 \%$ \\
$\begin{array}{l}\text { Solid or gaseous biomass } \\
\text { based electricity }\end{array}$ & $20-25 \%$ & - \\
$\begin{array}{l}\text { Co-generation systems fueled } \\
\text { by natural gas }\end{array}$ & $20-35 \%$ & $70-90 \%$ \\
$\begin{array}{l}\text { Fuel cells fueled by natural } \\
\text { gas }\end{array}$ & $40-60 \%$ & $80-95 \%$ \\
\hline
\end{tabular}

Source: Data from published studies.

\section{Use of Distributed Electricity Generation Systems in Hotels}

\subsection{Systems Using Fossil Fuels}

Distributed electricity generation systems using fossil fuels that can be used in hotels include:

a) Co-generation systems can be used in hotels producing heat and electricity while during the summer the produced heat could be utilized for cooling generation via thermal cooling systems. The preferred fuel in CHP systems is natural gas although biogas can be also used, if available, resulting in carbon-free heat and electricity generation. CHP systems are low carbon and high efficiency energy generation systems which are currently promoted due to climate change mitigation policies. Taking into account that most hotels require almost equal amounts of heat and electricity, during their operation (Table 1), the use of co-generation systems could provide not only the electricity needed but also part or all of their heat requirements,

b) Fuel cells can be also used fueled by $\mathrm{H}_{2}$ in hotels for heat and power generation. Various types of fuel cells (including phosphoric acid, solid oxide, molten carbonate, PEMs) are used while $\mathrm{H}_{2}$ can be produced either from natural gas reforming or from water electrolysis. Fuel cells are energy efficient systems while their investment cost is still high. However due to low environmental impacts during their operation many governments are supporting financially their installation in various applications. Fuel cells and CHP systems can cover significant amounts of heat and electricity requirement in hotels.

\subsection{Systems Using Renewable Energies}

Various DEG systems using renewable energies can be used in hotels including:

a) Solar energy with photovoltaic cells is an excellent option for green electricity generation

in locations with satisfactory solar irradiance. The technology is mature, reliable and 
cost-effective while it is currently used in many sectors. It is suitable for any hotel size and it can cover part or all of its electricity requirements. Solar-PV systems are desirable due to environmental advantages and their use is facilitated in many countries. Solar-PV panels can be placed on-site on the rooftop of hotel buildings or off-site in a nearby location. Use of solar electricity in hotels improves their energy performance while it decreases their carbon emissions.

b) Hybrid solar PV/T systems can be used in hotels co-generating hot water and electricity. Hotels require hot water and electricity particularly during the summer period. In areas with high solar irradiance some of them utilize separately solar thermal systems for DHW production and solar-PV systems for power generation. It is expected that this technology will be attractive for DEG in hotels provided that its reliability, maturity and cost-effectiveness is established and well proved.

c) Solar thermal power systems with parabolic troughs or discs can be used for co-generation of heat and power in hotels located in areas with high solar irradiance. This technology has not been broadly used so far in hotels or in other sectors. Like solar PV/T systems, mentioned previously, solar thermal power systems could be used in the future for DEG in hotels provided that their use will be competitive with other DEG technologies.

d) Wind turbines can be also used for DEG in hotels. Prerequisites for their use are a) Satisfactory average annual speed velocities in hotel's premises and b) Space availability for their satisfactory installation without disturbing hotel's operation. Few wind turbines generating electricity are currently installed in hotels worldwide.

e) Solid or gaseous biomass can be used for DEG in hotels. Solid biomass is already used for heat and hot water production in them. However its use for electricity generation or for CHP is rather limited. When biomass resources are available nearby the hotel area in attractive prices their use for DEG in hotels should be investigated. Burning of biomass for energy generation is related with $\mathrm{CO}_{2}$ emissions while solar and wind energy technologies are carbon free. However taking into account that photosynthesis is related with atmospheric carbon sequestration and neglecting the energy consumption during biomass harvesting, transportation and processing it can be considered that biomass burning for energy generation results in zero net carbon emissions.

The use of distributed electricity generation technologies in hotels is presented in Table 3 while the advantages and drawbacks regarding the use of distributed electricity generation systems in hotels are presented in Table 4. 
Table 3. Use of distributed electricity generation technologies in hotels

\begin{tabular}{|c|c|c|c|c|c|}
\hline $\begin{array}{l}\text { Energy } \\
\text { source }\end{array}$ & Technology & $\begin{array}{l}\text { Energy } \\
\text { generation }\end{array}$ & $\begin{array}{l}\mathrm{CO}_{2} \\
\text { emissions }\end{array}$ & $\begin{array}{l}\text { Current } \\
\text { commercial } \\
\text { applications }\end{array}$ & $\begin{array}{l}\text { Size of } \\
\text { hotels for } \\
\text { technology } \\
\text { use }\end{array}$ \\
\hline $\begin{array}{l}\text { Solar } \\
\text { energy }\end{array}$ & Photovoltaic & Electricity & No & Yes & All sizes \\
\hline $\begin{array}{l}\text { Solar } \\
\text { energy }\end{array}$ & $\begin{array}{l}\text { Hybrid } \\
\text { photovoltaic/thermal }\end{array}$ & $\begin{array}{l}\text { Electricity } \\
\text { and heat }\end{array}$ & No & No & All sizes \\
\hline $\begin{array}{l}\text { Solar } \\
\text { energy }\end{array}$ & $\begin{array}{l}\text { Parabolic trough, } \\
\text { parabolic disc }\end{array}$ & $\begin{array}{l}\text { Electricity } \\
\text { and heat }\end{array}$ & No & No & All sizes \\
\hline $\begin{array}{l}\text { Wind } \\
\text { energy }\end{array}$ & Wind turbines & Electricity & No & $\begin{array}{l}\text { Limited } \\
\text { applications }\end{array}$ & All sizes \\
\hline Biomass & $\begin{array}{l}\text { Burning, } \\
\text { Micro-turbines, } \\
\text { Reciprocating } \\
\text { engines, Ranking } \\
\text { cycle }\end{array}$ & $\begin{array}{l}\text { Electricity } \\
\text { and heat }\end{array}$ & Yes & $\begin{array}{l}\text { Limited } \\
\text { applications }\end{array}$ & Large \\
\hline $\mathrm{CH}_{4}$ & $\begin{array}{l}\text { Burning, } \\
\text { turbines, } \\
\text { Reciprocating } \\
\text { engines }\end{array}$ & $\begin{array}{l}\text { Electricity } \\
\text { and heat }\end{array}$ & Yes & Yes & Large \\
\hline $\mathrm{H}_{2}$ & Fuel cells & $\begin{array}{l}\text { Electricity } \\
\text { and heat }\end{array}$ & Yes & Yes & $\begin{array}{l}\text { Medium, } \\
\text { Large }\end{array}$ \\
\hline
\end{tabular}

Source: Data from published studies.

Table 4. Advantages and drawbacks regarding the use of distributed electricity generation systems in hotels

\begin{tabular}{|c|c|c|}
\hline $\begin{array}{l}\text { Distributed electricity } \\
\text { generation system }\end{array}$ & Advantages & Drawbacks \\
\hline Solar-PVs & $\begin{array}{l}\text { They can be easily used in } \\
\text { small and large hotels, } \\
\text { They are cost efficient in } \\
\text { areas with high solar } \\
\text { irradiance }\end{array}$ & $\begin{array}{l}\text { They generate only } \\
\text { electricity, } \\
\text { Their installation requires } \\
\text { large space }\end{array}$ \\
\hline Hybrid solar PV/T & $\begin{array}{l}\text { They can be used in areas } \\
\text { with high solar irradiance, } \\
\text { They require less space } \\
\text { compared with separate } \\
\text { solar-PV and solar thermal } \\
\text { heat systems, }\end{array}$ & $\begin{array}{l}\text { The technology is not } \\
\text { commercialized yet }\end{array}$ \\
\hline
\end{tabular}


They can co-generate heat and electricity

Solar thermal power systems They can be used in areas with high solar irradiance,

The technology is not They require less space compared with separate solar power and solar thermal heat systems,

They can co-generate heat and electricity

Wind turbines They can be used when wind They need more maintenance velocities in hotel premises are high

commercialized yet

They can co-generate heat

Solid or gaseous biomass and electricity, than solar-PV systems based electricity

Its operation is carbon free

Co-generation systems fueled

Their overall efficiency is by natural gas high,

They can co-generate heat and electricity

Their use is related with production of flue gases, Biomass should be available in nearby locations

They are suitable in medium and large hotels,

$\mathrm{CO}_{2}$ emissions during operation

Fuel cells fueled by natural Their overall efficiency is gas

high,

Their capital cost is high and they need financial support,

They can co-generate heat $\mathrm{CO}_{2}$ emissions during and electricity operation

Source: Data from published studies.

\section{Discussion}

Our results indicate that various DEG technologies can be used in hotels. Some of them, powered by renewable energies, generate carbon-free electricity while others have high energy efficiency and low $\mathrm{CO}_{2}$ emissions. Some of them generate only electricity while others co-generate heat and electricity. Various DEG systems are currently used in various applications in industry, agriculture, buildings as well as in stand-alone systems. Therefore there is enough experience regarding their operation, advantages and drawbacks. Solar-PV systems as well as CHP systems are already used in hotel industry. Small wind turbines and fuel cells have limited use so far in hotels worldwide. Taking into account that hotels require both heat and electricity in their daily operations the use of co-generation systems could provide the most of their required energy. Their use is desirable due to environmental benefits and in many cases it is supported from local and national authorities with financial and non-financial incentives. Our results are useful for hotel industry, local, regional and National 
authorities, electric grid operators as well as for manufactures and promoters of DEG systems. Present results do not indicate the economic benefits and the profitability of using the DEG technologies mentioned in hotels. They do not also indicate the social and environmental benefits due to lower fossil fuels use. More studies regarding the use of the abovementioned technologies in different hotel sizes is required in order to assess their profitability. Use of DEG systems based on renewable energies in hotels is highly depended on the local availability of renewable energy resources including solar irradiance, wind speed velocity and local biomass production.

\section{Conclusions}

The use of DEG systems in the hotel industry has been investigated. Various energy generation systems providing either electricity or both heat and electricity have been examined. Solar energy, wind energy and biomass can be used for electricity generation in hotels. Various co-generation systems including fuel cells can be also used. Co-generation technologies have high energy efficiencies while they are fueled with natural gas. Among DEG technologies examined solar-PVs, wind turbines, CHP systems and fuel cells are more or less already used in hotels. Systems fueled by solid or gaseous biomass depend on its local availability. Solar thermal power and solar PV/T technologies are promising for future applications in hotels but they require further development and improvements regarding their reliability and cost-effectiveness. Use of the abovementioned energy systems in hotels is attractive while it results in lower or zero $\mathrm{CO}_{2}$ emissions. Due to the fact that many hotels require almost equal amounts of heat and electricity the use of co-generation systems can cover most or all of their energy needs. Our results are important since they indicate that the use of green energy technologies for electricity generation as well as for co-generation of heat and power in hotels could minimize or zero their carbon impacts due to energy use. This is important for achieving the targets for climate change mitigation while many environmental conscious tourists would prefer to spend their holidays in a green hotel. Further research should be focused in the realization of various case studies concerning the use of the abovementioned DEG technologies in summer operating hotels of different sizes assessing the feasibility and the profitability of the abovementioned environmentally friendly energy systems. Apart from the benefits in hotel industry the social and environmental benefits derived from the use of DEG systems in hotels located in tourism dominated communities should be also investigated.

\section{References}

Alujevic, V. Z. (2006). Energy use and environmental impact from hotels on the Adriatic coast in Croatia - Current status and future possibilities for HVAC systems, Ph.D. thesis, Royal Institute for Technology, Sweden, 2006.

Best practice guide - Successful Energy efficiency Technologies integration in SME hotels, (2011), Intelligent Energy Europe - Hotel energy Solutions.

Bischoff, J. M. A., Hensen, J. L. M., Hassan Mohamed, M., \& Philips, C. (2016). Renewable energy technology feasibility study for a new hotel building in Amsterdam. REHVA Journal, , 
21-27.

Bohdanowicz, P., Churie-Kallhauge, A., Martinac, I., \& Rezachek, D. (2001). Energy-efficiency and conservation in hotels-Towards sustainable tourism, in $4^{\text {th }}$ International Symposium on Asia-Pacific Architecture, Hawai, April 2001.

Borello, D., Corsini, A., Rispoli, F., \& Tortora, E. (2013). A co-powered biomass and concentrated solar power Rankine cycle concept for small sized combined heat and power generation. Energies, 6, 1478-1496. https://doi.org/10.3390/en6031478

Cannistrato, G., Cannistrato, M., Galvagno, A., \& Tronato, G. (2016). The co-generation of service hotel complexes. A case study. Recent Advances in Energy, Environment and Financial Sciences, 19-25.

Chow, T. T., Tiwari, G. N., \& Menezo, C. (2012). Hybrid solar: a review on photovoltaic and thermal power integration. International Journal of Photoenergy. https://doi.org/10.1155/ $2012 / 307287$

Combined heat and power, An energy efficient Choice for mid-size to large hotels (2008), Combined Heat and power Partnership.

Good, C., Chen, J., Dai, Y., \& Hestmes, A. G. (2015). Hybrid photovoltaic-thermal systems in buildings - A review. Energy Procedia, 70, 683-690. https://doi.org/10.1016/j.egypro.2015. 02.176

Greenwood energy to develop second heat and power plant for Millennium hotels and resorts, 2012, Greenwood Energy.

Hidayatullah, N. A., Stojcevski, B., \& Kalam, A. (2011). Analysis of distributed generation systems, smart grid technologies and future motivators influencing change in the electricity sector. Smart Grid and Renewable Energy, 2, 216-229. https://doi.org/10.4236/sgre. 2011.23025

Hilton hotel tries to reduce energy costs by installing six wind turbines. https://skift.com/2014/01/30/hilton-hotel-tries-to-reduce-energy-costs-by-installing-6-wind-tu rbines

Hoshimi, Y., \& Nakajima, N. (2001). Application of fuel cell power units to hotels. Fuji Electric Review, 47(1), 7-8.

Hotel energy solution, Small wind turbine systems, Intelligent Energy Europe project. https://nepis.epa.gov

Huacuz, J. M. (1997). The "Villas Carrousel" PV-Wind hybrid project, in the workshop Photovoltaic-wind hybrid systems for remote power supply, in the Conference: Photovoltaic-wind hybrid systems for remote power supply, Cancun (Mexico), 21-25 April 1997

Huang, X., Zhang, Z., \& Jiang, J. (2006). Fuel cell technology for distribution generation: An overview, in IEEE ISIE, July 9-12, 2006, Montreal, Quebec, Canada. https://doi.org/10.1109/ 
ISIE.2006.295713

Indian hospitality industry takes to solar: case studies (2014). Energetica India, 4-5.

Joshi Hansen, Ch., \& Bower, J. (2003). An economic evaluation of small-scale distributed electricity generation technologies, Oxford Institute for energy Studies. https://doi.org/10.26889/1901795306

Moroni, S., Antoniucci, V., \& Bisello, A. (2019). Local energy communities and distributed generation: Contrasting perspectives and inevitable policy trade-offs beyond the apparent global consensus. Sustainability, 11, 3493. https://doi.org/10.3390/su11123493

Paliwal, P., Patidar, N. P., \& Nema, R. K. (2014). Planning of grid integrated distributed generators: A review of technology, objectives and techniques. Renewable and Sustainable Energy Reviews, 40, 557-570. https://doi.org/10.1016/j.rser.2014.07.200

Parpairi, K. (2017). Sustainability and energy use in small scale Greek hotels: Energy saving strategies and environmental policies. Procedia Environmental Sciences, 38, 169-177. https://doi.org/10.1016/j.proenv.2017.03.099

Perfetto, G. M., \& Lamacchia, F. P. (2016). Zero Energy Hotels and Sustainable Mobility in the Islands of Aegean Sea (Greece). International Journal of Clean Coal and Energy, 5, 23-36. https://doi.org/10.4236/ijcce.2016.52003

Purchala, K., Belmans, R., Exarchakos, L., \& Hawkes, A. D. (2006). Distributed generation and the grid integration issues.

Santamouris, M., Balaras, C. A., Dascalaki, E., Argiriou, A., \& Gaglia, A. (1996). Energy conservation and retrofitting potential in Hellenic Hotels. Energy and Buildings, 24, 65-75.

Sustainable energy for competitive tourist accommodation, RELACS, Intelligent Energy Europe, 2013.

Vourdoubas, J. (2019). Possibility of using solar energy for the creation of carbon neutral hotels in Mediterranean regions. Energy and Environment research, 9(1), 1-8. https://doi.org/10.5539/eer.v9n1p1

Vourdoubas, J. (2020). Possibilities of using fuel cells for energy generation in Greek hotels. Journal of Tourism and Hospitality Management, 8(1), 51-58. https://doi.org/10.15640/jthm.v8n1a5

\section{Copyright Disclaimer}

Copyright for this article is retained by the author(s), with first publication rights granted to the journal.

This is an open-access article distributed under the terms and conditions of the Creative Commons Attribution license (http://creativecommons.org/licenses/by/4.0/). 